\title{
An Interview with Philippe Sollers
}

\section{David Hayman}

Philippe Sollers is a controversial figure in French letters today. Editor of the left-wing journal Tel Quel, a periodical which has published some of the most daring critical and philosophical as well as political speculation (and polemics), Sollers is a prolific novelist and critic. $\mathrm{He}$ is also a protean figure capable of quick volte faces. His creative life began when at the age of 21 he published his first novel Une Curieuse solitude, an initiation narrative deriving largely from what he himself calls the classical French tradition but one which owes as much to Georges Bataille as it does to Marcel Proust. Though this book has been disavowed by its author, it bears witness to his precocious verbal gifts and his remarkable ability as a storyteller. The middle-class boy's premier amour with an unpredictable Spanish servant is somewhat more than the conventional tale in this genre. Appropriately, it is the only novel by Sollers that has been translated into English (A Strange Solitude, 1959).

Sollers' later fiction consists of a series of highly structured but plotless verbal tours de force, attempts to develop the "lyrico-epic" style which he described in this interview and which is best illustrated by the passage from $H$ published in this issue of The Iowa Review. A continuing series of permutations of language as a medium for semi-narrative forms and carefully integrated "political" statements, these "novels" have led to, rather than derived from, an appreciation of writer-heroes like Joyce, Pound, Mallarmé. Sollers' "fiction" has also tended to justify his position as leader (along with the novelist-critic Jean Ricardou and the brilliant and playful experimentalist Maurice Roche) of the post-New Novelists, a tendency loosely called the New-New Novel. The confusion generated by this tag has led Sollers to suggest that this "movement" be rebaptized The Wake in a punning play on Joyce's title.

It is perhaps important, since these writers and others like them are receiving an increasing amount of critical attention here and in France, that we not confuse them with the original New Novelists, most of whom might be called objectivist anti-novelists, whose work derives more or less directly from the central novelistic traditions they deliberately modify. The group represented by Sollers and centering around Tel Quel is more directly inspired by novelists and poets of the fringe, writers tending to violate the very ground rules of narration as well as the canons of taste and thereby discovering new uses for language. Among their heroes are the prose poet Lautréamont (Isidore Ducasse, 18461870), whose sadic visions inspired the early Surrealists; the playwright Antonin Artaud (1896-1948), who insisted on the role of theatre as a ritual implicating the audience in representations of its own impulses; and the recently rediscovered novelist-poet-essayist Georges Bataille (1897-1962), who preached the acceptance of the negative urges as essential to communal health, writing moving books based on paradox and hyperbole. Bataille's novel Le Bleu du ciel is a mas- 
terpiece of erotic romance. All of these writers, like those who belong to or can be associated with the newest French novel, have in common the fact that they escape categorization and have consequently been neglected by literary historians and teachers of literature.

The interview presented below mainly in the form of a monologue took place as a result of a chance encounter with Sollers in the company of Kurt Vonnegut (a very un-New-New Novelist) and the photographer Jill Krementz in a Paris café. Sollers was there to look over some photos taken of him by Jill Krementz and I was there to visit with Vonnegut. Round-faced, hair clipped square across his forehead, Sollers looked almost too young, and given his reputation, acted almost too amiable, though he refused to test his English and let slip an occasional snide remark. I noticed that the photos he preferred were those that made him look the Pierrot à la Jean-Louis Barrault, the tender-ironic victim. When I mentioned this to him, he quickly agreed, saying that that was the side of himself he preferred. After that remark, the interview seemed inevitable.

Our next encounter occurred over a tapeless tape recorder a month later. It was Sunday and I had forgotten the tape. We spent the time talking about Finnegans Wake and going over the translation of pages from book IV Sollers was about to publish in Tel Quel. The most striking thing about that translation (made by Stephen Heath but polished by Sollers) is its fidelity to the rhythms of the Wake, one of the subtler aspects of the "lyrico-epic" (in Sollers' sense) text. I was struck by the fact that the passage chosen by Heath is among the less complex verbally and that the translation is relatively free of the sort of multilingual puns which mark the original and which, according to remarks made in the interview, should appeal to Sollers.

That first meeting, punctuated by drinks with Sollers' wife, the intense and brilliant young theorist Julia Kristeva, was in Sollers' apartment. The second and more businesslike session took place in the office he shares with Marcelin Pleynet at the publishing house Aux Editions du Seuil. We spent a little over an hour taping an interview which attempts to situate the tendencies represented by Sollers' novels and outline his vision. Since Sollers speaks easily and with considerable clarity and since our subject was his own central preoccupation, my procedure was simple. I opened with a request that he give his version of the literary events leading up to the appearance of the Tel Quel group and their particular perversion of the novel. He proceeded from there to give me a flowing account, spiced with occasional asides (none of which I include below), an account which could serve the neophyte as an introduction to a fascinating new spectrum of writing, one which has a firmer intellectual and ideological base than do the current tendencies in America but which curiously parallels the work of some of our better young writers. Since the French movement is, as is usual in France, linked with critical and somewhat esoteric theoretical tendencies (with the work of the semiologist Roland Barthes, the philosopher Jacques Derrida and the post-Freudian psychoanalyst Jacques Lacan), and since Sollers alludes frequently to current terminology, I tried where possible to incorporate 
Sollers' own definitions and was obliged to include the occasional footnote to clarify allusions without impeding the flow of the discourse.

DH: Can you summarize the developments that led up to the sort of fiction now called the New-New Novel?

PS: The last 50 years produced three important literary movements in France beginning with the Surrealist period between 1920 and 1930. Then Existentialism dominated the post-WW II period, and during the decade of the sixties, we had the so-called Nouveau roman. These three movements were very differently constituted. We could say that Surrealism popularized, explicated, and publicized the big break (coupure) which occurred at the end of the 19th century with Mallarmé and Lautreamont. I believe that the essential elements of the crisis we are still living through derive from those experiments on language in literature. Surrealism simply took note of the remarkable literary events of that period. The Surrealists discovered and publicized Lautréamont, who would not have been read and perhaps not even published without Breton and Aragon in 1920. It was they who copied down the poems at the Bibliothèque Nationale. So you see they performed a belated exhumation under rather strange circumstances. Almost 50 years after Lautréamont wrote Les Chants de Maldoror the Surrealists made their discovery and extrapolated their theory using what they thought they understood of psychoanalysis, of language, of automatic writing, etc. There you have one of the areas of inquiry (problématiques).

Sartre's work derives in a sense from Surrealism. He became famous during a time of upheaval, the Second World War. Recognizing the irrationalistic limits of Surrealism, he tried to relocate the problem of literature within a conceptual field which is, in my view, more consistent with 19th-century Naturalism. He turned against the Surrealists' irrationalistic inflation while espousing a more realistic or naturalistic conception which he called the literature of engagement (littérature engagée) or evidential literature (la littérature du témoignage). His movement was regressive after Surrealism but, more importantly, it lacked or rather overlooked what are for us extremely decisive experiments, those carried out under the inspiration of Surrealism by people like Artaud and Bataille. Clearly, if we consider the problematics developed by Sartre at that moment, we see that he wanted to bypass Mallarmé, to avoid in-depth interpretations of poetic language, and above all to limit the possible influence of Artaud or Bataille. Or at any rate, he failed to recognize how fundamental their experiments were. I believe that it was a rather hollow, empty moment, but we can justify it in the light of the disruption caused by the Second World War, and above all by the already perceptible displacement of the European cultural scene toward the United States . . . toward a decentralization of world history, an unfocusing. (I should of course have spoken of the other movements of the twenties, Futurism, Dada, etc. But this is just a schematic overview.) 
But then, during the fifties and sixties (we might speak half-seriously of a Hegelian thesis, antithesis, and synthesis), with the New Novel, there is an apparent return to literary experimentation, to the problem of language in literature. To my mind, this is a rather feeble and didactic phenomenon, a movement which harks back to but fails to take into account the experiments of Mallarmé and Lautréamont and above all the decisive and fundamental linguistic experiments of Joyce. The Nouveau roman came to rather academic conclusions about the most noteworthy experiments with language in the 19th and 20th centuries.

Take, for example, the case of Joyce. Within the French context, a context still xenophobic and nationalistic, the major movements almost completely overlooked Joyce. Breton, you know, condemns Joyce, saying that in the end he returns to the arbitrary, but really he had no right to say that. DH: You know Joyce had similarly unkind things to say about the Surrealists . . . PS: Yes, of course the feeling was mutual. But what counts is that the appearance of a phenomenon as important as Joyce collides in France with two other phenomena. First, there was that critical censor, the $\mathrm{NRF}^{*}$, with its neoclassical and bourgeois conception of literature: Gide, Valéry, etc. . . . Proust! I am alluding to a conception or rather to a syntax, to a :way of writing sentences, making them unfold, a conception anchored in French classical rhetoric. So, there was no chance of really understanding Joyce's contribution in Ulysses and Finnegans Wake. But there was also what we could call the Surrealist refusal, the failure to understand that Joyce goes beyond the problematics of automatic writing, of the marvelous or of the simple occult, that is, beyond the domain of Surrealism. And we can see that Existentialism could hardly have been aware of the great new continent opened by Joyce since it harked directly back to 19th-century Naturalism. The space-time, the Einsteinian side of Joyce, was not perceived by Sartre in its modernity, as a seismic shudder within language itself. The same goes, I think, for the Nouveau roman. Even if there is a sort of modernity within the problematics of language, we can't think of the Nouveau roman (excluding Beckett, who is himself a post-Joycean) as truly aware of Joyce's contribution.

DH: We should say more about that aspect and perhaps add that Butor has written a good deal on Joyce, that he is the only one . . .

PS: Yes, Butor is perhaps the least xenophobic of the French writers. But I don't think that Butor's novels draw upon his understanding of Joyce. At any rate, if during the sixties there was some slight awareness and elaboration of the essential problem of literature, this 20th century of ours has taken a long time to achieve a minimal sense of the real problems to be faced by literature. I think it was only about seven or eight years ago, in response to shocks administered to language both by psychoanalytic theory and by

\footnotetext{
- The Nouvelle Revue Française dominated French publication from the twenties to the sixties.
} 
history, that we [French] really entered the 20th century. By that time we were almost in the 21st.

DH: Let's talk about the problems of the novel to which you referred earlier.

PS: It seems to me that for a century now language has been undergoing a revolution. For one thing, we are increasingly aware that there can no longer be purely national languages. The isolation of different languages and of different nations each with its language is being severely tested. We see a sort of intercultural movement of which I think a writer like Joyce is the deepest sort of exemplar. He grasped the situation radically, understanding that we were entering a new world of which he tried to write the gospel, at once ironic and serious. Which means he understood that the definition of the human subject through his language and in history was entering an unprecedented phase of transmutation. We would save a good deal of futile talk if we were to accept Joyce's project as fundamental; for I think Joyce understood that we were beginning to reshape the relations between man and language and history.

That's the central issue. People still perceive the problem of literature in 19th-century terms. Repeatedly, we've seen literary errors committed, great errors, occasionally tragic ones (like ... Socialist Realism). Such errors are a function of metaphysical suppositions dating from the last century. They're still fixed by ideology despite the progress made by the sciences, despite historical growth, despite the shocks experienced by our species, even, I'd say (and this is the strangest fact), despite the revolutions that have occurred within the other arts. Traditionally, we stick to archaic literary ideologies even while painting and music are in full cataclysmic bloom. All of this suggests that what happens in the spoken language, a language made up of words, syllables, phonemes, etc., is something very dangerous. That's why it is so carefully regulated, changes are so brutally suppressed. As opposed to what happens simply visually or audibly, that which is charged with significance in language is watched over, subjected to limitations . . .

DH: By whom?

PS: By no one in particular. I think one has to agree that there is an element of repression (refoulement) in the handling of language, that there is, as Freud says, not only the unconscious but also repression. There is a primal repression, repression in that society is constituted as communication, as language functioning as communication between men. I don't think we can make a true history of the literature of this last century without taking into consideration the fact that the subversion of language perpetrated by Mallarmé, Lautréamont, Joyce, brings subversion to the very limits of what society can tolerate, to the threshold of the intolerable. Of course, we know that there are university lectures, there is criticism which takes these subversions into account, generally a good while after the fact. When Finnegans Wake was published I doubt that there were many articles to mark its appearance.

DH: Three or four.

PS: Very few. I am struck when I read Joyce's correspondence by the impressive 
machinery he felt obliged to mobilize just to enable himself to write Finnegans Wake between 1923 and 1939. There is evidence of elaborate scenesetting which proves he was aware that the extracts he was publishing during this period were quite dangerous. So he was obliged to pretend that he was engaged in writing some sort of "great work," but hiding the title. He worked out a secret strategy which finally seems to me to be a mode of protection. It seems that he knew he was doing something dangerous and unacceptable.

DH: Is it dangerous in a social (or psychic) sense or in a literary sense?

PS: I'd say both. It's dangerous in an almost physical sense, on the level of mental health, for example, and even of physical health. I don't think we can completely separate Joyce's blindness, his entry into the ocular night, and his profound experiment with language. There, you see my conception goes quite far. I'd even say that it is something which might be verified with reference to someone else, for example, Artaud." I believe that he who enters into the very mechanism of language takes risks which are social risks. For example, he cuts himself off from all means of subsistence. Joyce owed his material well-being to the good offices, occasionally conditional, of a certain number of ladies. Mrs. McCormick wanted him to submit to analysis by Jung. I am speaking, of course, of personal risks. Take, for example, Joyce's daughter ...

DH: There you are closer to something significant. Joyce was really afraid of going mad ...

PS: You mention in one of your articles that the word mad was applicable or at least applied to him. And Jung, speaking of Ulysses after all . . . Here we enter immediately into the 20th century with the problem of madness. From 1920 on, the question was being asked, after WW I. Though it had already been asked by Mallarmé and Lautréamont, the problem had not been raised with the same urgency. Of course we can follow it back to Hölderlin, Nerval.

DH: It's essentially a Romantic problem.

PS: It is a Romantic problem which later loses its form, its Romantic appearance, to go much deeper. That is, to touch more and more immediately the very roots of language. No one is less mad than Joyce or than Artaud (to my mind). I have a clear sense that what is being torn by such writers is to be remade as a new type of rationality involving the whole of our civilization but that there are few who would take the sort of risks implied.

DH: Perhaps we can return once more to history, to contemporary history and particularly the history of the Tel Quel group and of novelists who do not belong to the group but who nevertheless are doing something similar to what you are doing.

PS: I'l talk only about the literary aspects of Tel Quel, though Tel Quel, as you know, has a number of other sides. It's a sort of dialectical machine.

\footnotetext{
- Artaud's madness is one of the crucial literary events of this century thanks to the attention paid it by theorists like Sollers.
} 
According to its subtitle, it treats literature, philosophy, science, politics. There is a whole dynamic history to be written some day, not now, since we are still in process. The point is that these several aspects interrelate. The originality of the review, like that of certain others which have the same concerns, lies in the awareness that we must put literature within a general context of development, a context at once historical, political and philosophical. Further, we must locate literary practice at the very center of these several disciplines, these several realities. At the end of the 20th century we are abandoning the idea that literature has to be written by a "maudit," an individual set apart and seemingly enclosed by his creative concerns, one who can see the outside only through certain very narrow apertures. I am perhaps a bit naive, but I feel we must not encourage the belief in the outcast creator, in the necessary tragedy of literary creation. It is precisely in this area that we must leave Romanticism behind.

To get back to literature, I think there have been a great many things of rather unequal value done in the past five or six years, but these works constitute a creative study whose prime concern is to X-ray our culture as it has existed these 2,000 years. Clearly, what we have is an attempt to achieve in literature an enormous anamnesis. There you have the project that was already preoccupying Joyce. That is, we are abandoning the rather cramped vision of those who preached Naturalism, psychological fiction, description of a limited social milieu within a given historical period. Of course, this sort of writing is still being done. It still sells, if you will. But in fact it is dead.

The publications of the Tel Quel group attempt to approximate a language which could be prodigiously retroactive, one which would have the analytic capacity to penetrate the history of humanity viewed as a sort of great myth. I think this project prolongs and subsumes that of Mallarmé, Joyce, etc. It is an attempt to unify history through the unnumbered strata of civilizations, cultures and languages ...

DH: But you aren't trying to fix or fossilize them.

PS: Quite the contrary, we're trying to analyze them, that is, in a sense to dissolve them, to dissolve the frontiers, the compartments, and by dissolving this weighted past to project it into the future.

DH: In this connection, could we talk about Derrida?*

PS: Derrida, yes, since 1965 he has been developing an important theoretical position. I have just recently said that at the moment the [French] literary breakthrough occurred, Derrida was there to reflect on it. Unlike other philosophers he recognized that, though seemingly outside the domain of philosophical discovery, efforts like those of Mallarmé, Artaud, and even of Joyce are important to philosophy. One could say that literature is having its bizarre revenge, since during its "lifetime" it tends to be dominated,

- Jacques Derrida, author of De la grammatologie and La dissémination, has published regularly in Tel Quel. He has written a long essay on Sollers' fiction. 
overshadowed, repressed by the learned disciplines. Now knowledge seems to have been struck by literature; learning is obliged to recognize something learned disciplines of the time when the writing was done did not know. I think that is what literature is for us, something which tells learning what learning does not want to know. This is important for me because it occurs precisely in the deepest most repressed part of language, emitting a charge that obliges the conscious subject (the subject of the theoretical discourse or reflection is always forced if it wishes to understand what is written) to excise, to choose, to limit or to render linear through an explication. So we move toward a language, toward phenomena of very great condensationexplosion which are close to everything which learning energetically seeks. (I am using by preference physical or biological metaphors to avoid excessive idealism at this level.) In literature, then, we have something which intervenes to affect knowledge, by which I don't mean what we tend to call science. Scientific discourse has no need to know the subject [of its discourse].

DH: What do you mean by the term subject?

PS: By subject I mean the subject (subjectivity) of science. Science is in fact something which has no need of a subject. That is one of Lacan's theses. Science bases itself on the principle that it should not be concerned with its own subject, the subject of its discourse. One does not ask a mathematician or a biologist to include himself (s'impliquer) in his science. At least, if he does (and who knows about such things?) he is not obliged to say he is doing so. It is commonly accepted that a scientific discourse can be made by a learned man who, in terms of his own subjective nature, may exhibit a remarkable naivety. You know it is not unusual to find a scientist who holds to infantile religious beliefs even if he is among the scientific geniuses of his time.

You may take what I am saying as a trope. I've chosen this trope because the domain and responsibility of literature is precisely this subject lacking in science, lacking so that science can function. Just imagine what would happen were a learned man, say Einstein during Joyce's period, to have Joyce's subjectivity, his capacity to move about within language (se déplacer dans la langue). It is inconceivable. We would have had in the same man the author of the theory of relativity and a mind capable of writing Finnegans Wake . . . inconceivable: you don't find two such disparate forms of discourse in the same man. You see, there we have a tragic division. On the other hand, a very great writer can have illusions, can be naive in the realm of scientific theory.

Between literature and science, the one eliciting the subject, the other excluding it, we have philosophy. Philosophy must take into account what

* The psychoanalyst Jacques Lacan, who has revolutionized French Freudian thought, is among the most-cited (and least accessible) thinkers in Paris today. 
science forces it to discover. For example, a philosopher as important as Derrida must take into account the contributions of a humanistic science like linguistics even if he feels obliged to criticize the naive philosophical presuppositions of linguistics. Linguistics still forces philosophy to state more precisely the problems raised by language. Or, from another angle, philosophy may concern itself with the literary subject in full ferment. Of course it is free to deal or not to deal with literature, but if it does take it into consideration, it is several steps ahead. Derrida's philosophy is deeper, subtler, more fully elaborated than Sartre's, when it comes to questions of language. That should be evident. And this enormous field (dispositif) of concerns, as I see it, is itself caught up in history, where politics plays its role as do international power plays. That will give you some idea of how I view the concept "world." We see the relations among the various modes of discourse a bit more clearly now than we did 10 or 15 years ago. It is in a sense the program and the role of Tel Quel to clarify these relations.

DH: What about the membership of the Tel Quel group and their specific contributions to the literary facets of your program?

PS: I think there was a period which we could call formalist. That is, for quite a long time, the writers in the group, even I, and many of those working at Seuil either in poetry or in the novel were ...

DH: Would you include yourself when you wrote Une Curieuse solitude in that category?

PS: That's my pre-history. Une Curieuse solitude was written when I was very young and according to the code of the French literary tradition, at once neo-classical and ... That's why I've suppressed it because I think of it as a stylistic exercise, almost as a copy. All right, it was published. It belongs to history. But I can't honestly say that it counts for anything.

To get back to what we were saying, there was an attempt by poets and novelists to impose, and this was part of the general tendency of the time in the domain of knowledge, to make language the area of inquiry (problématique). That was the emphasis everywhere, but I think that that approach has been exhausted. Within the last two or three years we have recognized its limits.

DH: Who are the novelists you're talking about and what were their procedures?

PS: There were of course [Jean Pierre] Faye, myself, Maurice Roche, and in poetry, since I think poetry played its part, people like Denis Roche, [Marcelin] Pleynet, etc. were very important. They managed to introduce disorder, a real and efficacious disorder, into the poetic code. Besides, they were capable of breaching national frontiers. Denis Roche, for example, helped introduce Pound to France. That in itself is an important accomplishment. $\mathrm{He}$ translated the Pisan Cantos, etc. You know, we began emphasizing Pound very early in Tel Quel, publishing translations of the Cantos. We felt that, given the general ignorance, we had to emphasize his role and especially the cultural "problematics" he raised. In this connection I should mention 
Butor's contribution and pay my respects to his cultural awareness. Incidentally, I would place Butor in the middle of this formalist tendency, along with Robbe-Grillet, etc. ${ }^{*}$

We arrived rather quickly at the saturation point. That is, as soon as the "problematics" of language as question, as opacity, as locale of literature . . . You know, that isn't a generally accepted position even today. There are many who don't think that literature takes place in language, which is too bad, since language is also the matter of literature. Still, I think we have managed to establish our view firmly enough that there can be no turning back. It seems unlikely that in the future, barring a return of the barbarians, or a not-inconceivable regression . . . at any rate, it is unlikely that we will again see a metaphysics which preaches that language is transparent, that it is not the locus, the complex instrument, the material, and the material in motion within which thought and literature take place. At least that much has been achieved.

But finally, it isn't enough to make this an accepted position. I think that the period through which we are now living and which began a few years ago has different preoccupations. Once this awareness [of language as opacity] is established, we have to admit that the subject of that insistence can be censored. That is, there is what I would call a formalist error, which would treat the literary experience as a sort of neutrality, existing in language alone. There can be a sort of positivism or neo-positivism as in the theories of Ricardon, * who tries to globalize his views, to draw universal consequences from the New Novel while significantly ignoring both psychoanalysis and history. In my view this neo-positivism is not very productive. Why? Because while we must posit language as the locus of the literary act and even of thought, once this has been admitted, if we are inflexible on this point, everything will once more ossify, producing a pale monotony. Once again we will miss the most profound aspects of the literary experience. For example, what Joyce brought us in the way of a universal problematics, one which truly displays humanity while recounting the eternal return, one that in the process touches upon many many events, becoming enormously inclusive. I think we are in a period when we must, and perhaps I am alone in doing this, we must insist on the need for a resurgence of these epic functions, and even of the lyric. I think that this is particularly difficult in France.

DH: You obviously aren't talking about any traditional epic functions here. What about the lyric?

PS: It is neither a traditional lyric nor a traditional epic, but I don't think we

- There is an interesting contradiction here, given Sollers' dissociation from the New Novelists. But then he is pointing beyond this "formalistic" stage to a new verbal phase.

* Jean Ricardou, novelist and critic, has written two theoretical studies: Problemes du nouveau roman and Pour une théorie du nouveau roman. 
can overlook what the lyric and the epic possess in the way of role, of question ... Let me explain what I mean. For me lyricism is a question of the availability or inaccessibility of rhythm, of metre, of the musicality of language, the question of its multiple audibility, of its scansion. It would not in my opinion be very interesting to say in a prosaic or syntactically correct statement that language is a problem. Language is a problem, but not in the same way that tomatoes or electrons are problems. It is a problem which possesses automatically its own internal burden, which one can't neglect. That is, the problem of language is plugged directly into and hence derives directly from the big questions of scansion, rhythm, the underlying pulsations of language which no literature, if it is to be truly for its period and society, can underestimate without becoming expendable. That, for me, is lyricism. It is the upsurge of the subject! or of what I have been calling the subject: the possibility of saying " $\mathrm{I}$ " within, at the heart of language. Language is not neutral, but it needs to be taken over by a subject, a subject I would call illimitable, numberless, rather like in Finnegans Wake. That is, it is not a biographical subject, the psychological subject, it is not a "me."

During our conversation, Sollers stressed the audible qualities of his prose, its rhythms. At my suggestion he recorded a passage of his own choosing. The result was a remarkable dramatic reading of the following sequence on Ezra Pound viewed from a Marxist if not Maoist perspective, a reading which was enormously helpful to the translator, aware of the subtler rhythmic values, the "lyric" aspects as well as the "epic" ones. It is fairly obvious that the unpunctuated prose, much like Molly Bloom's monologue, tends to punctuate itself when read and especially when read aloud. The taped reading underscores another fact, that the text lends itself to a quasi-classical declamation, that Sollers is above all a master of verbal rhythms, and oddly enough, given the seeming shapelessness of his prose, of "le mot juste." As the passage will show, he is also a good mimic. American readers will recognize not only the passages taken from Pound together with the allusions to the poet's life and work, but also the characteristic emphases and the breadth of allusion. Clearly, this passage constitutes an homage to an acknowledged master as well as an attempt to reconcile opposing views of social morality. This is narrative of a new sort, part of an on-going process of self-disclosure more radical than anything in the New Novelistic tradition. Reproducing in English wordplays and tonal shifts, preserving ambiguities without promoting obscurity, Inez Hedges has produced a fine introduction for English-speakers to one of the most controversial and gifted of the young French novelists. 